\title{
Ovum pick up in horses: Results and consequences for follicular growth and oocyte quality
}

\author{
Wilhelm Kanitz' , Frank Becker' ${ }^{7}$, Hannelore Alm, Helmut Torner ${ }^{1}$ und Gerd Nürnberg ${ }^{2}$ \\ Research Institute for the Biology of Farm Animals, Department of Reproductive Biology' and Department of Genetics and Biometry ${ }^{2}$, Dummerstorf, Germany
}

\begin{abstract}
Summary
The aim of the work was to examine the influence of the factors such as follicle diameter, stage of oestrous cycle and cycle activity, on the results of the ultrasound guided transvaginal follicular aspiration. Furthermore, the influence of consecutive follicular aspirations on follicle populations, the recovery rate of cumulus-oocyte-complexes (COCs), the morphology of the COCs as well as the chromatin configuration was characterised. The ultrasound guided follicle aspiration was carried out at cyclic and acyclic warmblood mares. The computersonograph CS 9000 of Hitachi was used for this purpose. The frequency of the probe was $6.5 \mathrm{MHz}$ and the aspiration vacuum ranged between 0.2 to 0.3 bar. The judgement of the COCs was carried out on the basis of morphological criteria. For the analysis of the chromatin configuration, the oocytes were stained with orcein. Results obtained show that the recovery rate for COCs decreased significantly with an increasing follicle diameter. The stage of oestrous cycle and cycle activity also had an influence on the recovery rate. This was significantly higher when acyclic mares or mares on the 5th day after ovulation were used as oocyte donors in comparison to mares on day 12 of the oestrous cycle. Consecutive follicle aspiration sessions in the same animals (average interval between the aspiration sessions: 7 days) led to a significant reduction of the number of aspirated follicles per mare and aspiration session. The average number of recovered COCs decreased from 3.5 to 2.2 per session and mare after consecutive sessions. The number of aspirated follicles in the size classes 10 to $20 \mathrm{~mm}, 21$ to $30 \mathrm{~mm}$ and $>30 \mathrm{~mm}$ decreased significantly in the course of consecutive aspiration sessions. Consecutive aspiration sessions led to a significant increase of the portion COCs with compact cumulus. In parallel, the portion of oocytes with chromatin in the germinal vesicle stage rose significantly from $36.8 \%$ to $65.9 \%$ whereas the portion of oocytes in germinal vesicle break down to metaphase I stage decreased significantly. It can be concluded that repeated follicle aspirations can be carried out without problems and without impairment of the later fertility of mares. The results of the follicle aspirations are influenced fundamentally by the ovarian follicular dynamic. Repeated follicle aspiration sessions within the same mares are an useful method to standardize aspirable follicle populations of the ovaries. Furthermore, the quality of the recovered COCs becomes more uniform.
\end{abstract}

Keywords: horse, oocyte recovery, ultrasound

\section{Ultraschallgeleitete Eizellgewinnung beim Pferd: Ergebnisse und Konsequenzen für das Follikelwachstum und die Oozyten- qualität}

Das Ziel der Arbeit bestand in der Untersuchung der Einflüsse, die von den Faktoren Follikeldurchmesser, Zyklusstadium und Zyklusaktivität auf die Ergebnisse der ultraschallgeleiteteten transvaginalen Oozytengewinnung ausgehen. Darüber hinaus sollten die Einflüsse, die von aufeinanderfolgenden Follikelaspirationen auf Follikelpopulationen, die Gewinnungsrate für Cumulus-Oozyten-Komplexe (COK), die Morphologie der Cumulus-Oozyten-Komplexe sowie die Chromatinkonfiguration der Oozyten ausgehen, charakterisiert werden. Die ultraschallgeleitete Follikelaspiration wurde an zyklischen und azyklischen Warmblutstuten durchgeführt. Zum Einsatz gelangte der Computersonograph CS-9000 von Hitachi. Die Frequenz der Schallsonde betrug 6,5 MHz, und das Aspirationsvakuum lag im Bereich von 0,2 bis 0,3 bar. Die Beurteilung der Cumulus-Oozyten-Komplexe erfolgte anhand morphologischer Kriterien. Für die Analyse der Chromatinkonfiguration in den Oozyten wurden diese mit Orcein gefärbt. Aus den erzielten Ergebnisse geht hervor, dass die Gewinnungsrate für COK mit zunehmendem Follikeldurchmesser signifikant abnahm. Auch das Zyklusstadium und die Zyklusaktivität hatten einen Einfluss auf die Gewinnungsrate. Diese war bei Verwendung azyklischer Stuten und bei Verwendung von Stuten am 5. Tag post ovulationem signifikant höher als bei Verwendung von Stuten am Tag 12 des Zyklus. Wiederholte Follikelaspirationen bei den selben Tieren (durchschnittliches Intervall zwischen den Aspirationssitzungen: 7 Tage) führten zu einer signifikanten Abnahme der aspirierten Follikel/Stute und Aspirationssitzung und zu einer Abnahme der gewonnenen COK/Stute und Aspirationssitzung von durchschnittlich 3,5 COK auf 2,2. Die Gewinnungsrate für COK wurde durch die wiederholten Aspirationssitzungen nicht beeinflusst. Demgegenüber nahm die Anzahl Follikel in den Größenklassen 10 bis 20 mm, 21 bis 30 mm und > 30 mm im Verlauf der aufeinanderfolgenden Aspirationssitzungen signifikant ab. Aufeinanderfolgende Aspirationssitzungen führten zu einer signifikanten Zunahme des Anteils COK mit kompaktem Cumuluszellverband. Parallel dazu stieg der Anteil Oozyten mit Chromatin im Germinalvesikelstadium signifikant von 36,8 \% auf 65,9\% an, wohingegen der Anteil Oozyten mit beginnender Kernreifung signifikant abnahm. Aus den Untersuchungen kann geschlussfolgert werden, dass die wiederholte Follikelaspiration problemlos und ohne Beeinträchtigung der späteren Fertilität bei Stuten durchgeführt werden kann. Die Ergebnisse der Follikelaspiration werden wesentlich von der ovariellen Follikeldynamik beeinflusst. Wiederholte Follikelaspirationen bei den selben Stuten sind eine Methode, um die für eine Follikelaspiration nutzbaren Follikelpopulationen der Ovarien zu vereinheitlichen. Darüber hinaus wird die Qualität der gewonnenen COK vereinheitlicht.

Schlüsselwörter: Pferd, Eizellgewinnung, Ultraschall

\section{Introduction}

During the last decade the technique of transvaginal ultrasound-guided follicle puncture in mares, described as ovum pick up (OPU) synonymously, was developed (Duchamp et al.
1995; Kanitz et al. 1995; Meintjes et al. 1995; Brück et al. 1997; Goudet et al. 1997). This technique offers the possibility of repeated recovery of biological substrates, i.e. follicular fluid, granulosa cells and cumulus-oocyte-complexes (COCs) from individual follicles. Because examinations about factors 
influencing results of follicular aspiration are limited and because little is known regarding the quality of the oocytes so collected and the effect of follicle aspiration on subsequent follicular growth and oocyte quality we investigated the influence of following factors on results of recovery: vacuum, day of oestrous cycle, follicular diameter. Moreover, the influence of repeated ultrasound-guided follicular aspiration on number and diameter of follicles $\Delta 5 \mathrm{~mm}$, recovery rate for COCs, COC morphology and chromatin configuration in oocytes were investigated.

\section{Materials and Methods}

\section{Experiment 1}

One hundred and thirty-four follicles from 14 slaughterhouse ovaries ranging from 5 to $46 \mathrm{~mm}$ in diameter were aspirated in vitro with two different vacuum pressures ( 0.2 or 0.4 bar). The aspiration system used was identical with that used in experiment 2 and 3 .

\section{Experiment 2:}

Twenty seven warmblood horse mares weighing 450-500 kg were used as oocyte donors. Follicles of cyclic mares were aspirated either on day 5 or 12 of their oestrous cycle from April till November. Noncyclic mares were used during December and January. Ovarian activity was observed by daily ultrasound control of follicular dynamic. The computer sonograph CS-9000 from Hitachi was used in the experiments described. Mares were given a sedative $(1 \mathrm{ml}$ Domosedan ${ }^{\circledR}$ /Orion Corporation) prior to aspiration. Under antiseptic precautions a $6.5 \mathrm{MHz}$ sector scanner, placed on a carrier, which carried also the aspiration needle, was used for visualization of follicles. The outer diameter of the aspiration needle was $1.1 \mathrm{~mm}$ whereas the inner diameter was $0.9 \mathrm{~mm}$. The length of the needle was $80 \mathrm{~mm}$. For the aspiration a vacuum of 150 to $225 \mathrm{~mm} \mathrm{Hg}$ (0.2 - $0.3 \mathrm{bar}$ ) was used. This vacuum resulted in 30.1 to $42.6 \mathrm{ml}$ aspirated fluid per minute (Kanitz et al. 1995). The possibility of simultaneous or successively aspiration and flushing of follicles was given by a bitubular connection between the needle and the vacuum system. After aspiration, follicles were flushed up to 4 times. All aspirated follicular fluids were transported to the laboratory and the fluid from each individual follicle was examined separately. The follicular fluid was poured into sterile petri dishes and searched for oocytes with the aid of a stereomicroscope at a magnification of $x 16$. Oocytes were transferred into holding medium (M 199 with Hank's salts and 25 mM Hepes buffer) and classified as described below.

\section{Experiment 3}

Altogether 6 healthy warmblood horse mares aged 4 to 13 years and weighing between 500 and $600 \mathrm{~kg}$ were used from March to November 1996 and 1997. Before starting with the experiments mares showed regular oestrous cycles. Follicular aspiration sessions were performed 6 to 30 times per mare. The sessions were defined as "cyclic" when mares had at least one regular cycle including ovulation prior to aspiration. These cyclic aspiration sessions were followed by consecutive sessions at 4 to 12 day intervals (mean: 7 days). The aspiration system and the applied vacuum were identical with those in experiment 2 .

Classification of cumulus oocyte complexes and investigation of chromatin configuration

The oocytes were classified into 4 groups according to their cumulus morphology (Torner and Alm 1995): oocytes surrounded by compact cumulus cells (I), oocytes with expanded cumulus cells (II), oocytes with few cumulus layers (III) and denuded oocytes (IV). To characterise the chromatin configuration of compact $\mathrm{COCs}$ in relation to cyclic and consecutive sessions 79 COCs were fixed and cytological analysed. For this purpose the cumulus cells were removed by treatment with sodium citrate (3\%). To classify the stage of nuclear maturation as germinal vesicle (GV), germinal vesicle breakdown (GVBD), metaphase 1 (M 1) or metaphase II (M II) oocytes were fixed with acetic alcohol (1:3, acetic acid:ethanol) and stained with $1 \%$ acete-orcein.

\section{Results}

Results of experiment 1 are shown in Table 1. Altogether 37 COCs (27.6\%) were recovered from 134 aspirated follicles. No significant difference in recovery rate (28.8\% vs. $26.4 \%$ ) was observed when different vacuums ( 0.2 bar or 0.4 bar) were used for aspiration. The recovery rate tended to decrease when follicular diameter increased. This tendency was independent of the vacuum applied.

A total of 332 follicles, ranging in diameter from 4 to $55 \mathrm{~mm}$, were aspirated in experiment 2. Most follicles present on the ovaries at the time of aspiration had diameters of 10 to 20

Tab 1 Results of follicular aspiration in vitro in relation to applied vacuum and follicular size

Ergebnisse der Follikelaspiration in vitro in Abhängigkeit vom Vakuum und dem Follikeldurchmesser

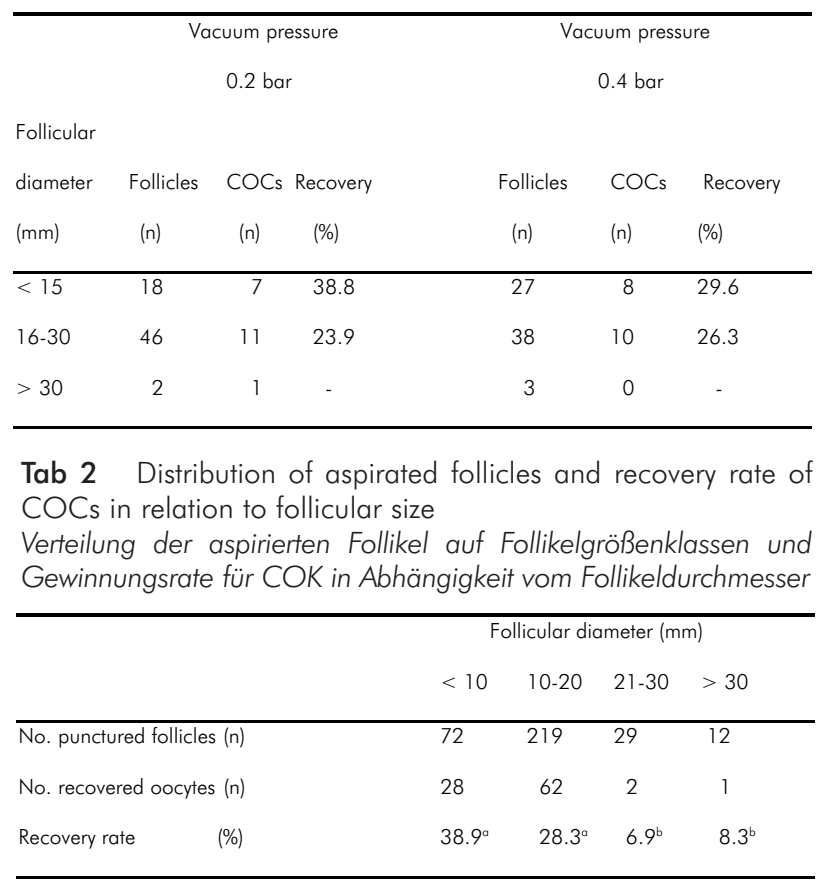


mm (85\% of all follicles). A mean of $12.3 \pm 8.7$ follicles per mare were aspirated. The recovery rate of COCs decreased significantly with increasing diameter of aspirated follicles (Tab. 2). This result was independent of the stage of oestrous cycle.

The mean number of recovered oocytes was $3.4 \pm 1.5$ per mare. Recovery rate, and in this way, mean number of recovered COCs per animal were influenced by time of aspiration in dependence on stage of oestrous cycle (Tab. 3). More COCs per animal were recovered when mares on day 5 of oestrous cycle or noncyclic mares were used in comparison to mares on day 12 of the oestrous cycle.

Tab 3 Results of follicular aspiration in relation to stage of oestrous cycle

Ergebnisse der Follikelaspiration in Abhängigkeit vom Zyklusstadium

\begin{tabular}{llccc}
\hline Stage of oestrous cycle & & day 5 & day 12 & acyclic \\
\hline No. of mares & (n) & 8 & 8 & 11 \\
No. punctured follicles & (n) & 99 & 97 & 136 \\
No. recovered oocytes & (n) & 26 & 12 & 55 \\
Recovery rate & (\%) & $26.3^{a}$ & $12.4^{b}$ & $40.4^{c}$ \\
\hline
\end{tabular}

$a: b, a: c, b: c \quad P<0.05$

In experiment 3 altogether 88 follicular aspiration sessions were performed in 6 mares either after a normal cycle ("cyclic" sessions) or at 4 to 12-day intervals ("consecutive" sessions). During these aspiration sessions 1.268 follicles were aspirated and 280 COCs were recovered. On average 14.4 follicles were aspirated per mare and session leading to a mean of 3.2 COCs. A mean recovery rate of $22.1 \%$ was achieved. There was no difference in recovery rate between cyclic and consecutive sessions (Tab. 4). The mean numbers of aspirated follicles were significantly different between cyclic and consecutive sessions (15.3 vs. 10.8, respectively) leading to a lower number of COCs in consecutive sessions (3.5 vs. 2,2 respectively, $\mathrm{P}=0.08$ ).

Tab 4 Results of cyclic and consecutive follicular aspiration sessions

Ergebnisse der Follikelaspiration in Abhängigkeit vom Typ der Aspirationssitzung

\begin{tabular}{|c|c|c|c|c|c|c|c|c|c|c|}
\hline \multirow[t]{3}{*}{ Aspiration } & \multirow[t]{2}{*}{ Mares } & \multicolumn{9}{|l|}{ Number } \\
\hline & & tions & & & & & & & & (\%) \\
\hline & (n) & (n) & $\Sigma$ & LSM & SE & $\Sigma$ & LSM & SE & LSM & SE \\
\hline
\end{tabular}

\begin{tabular}{lllllllllll} 
Cyclic & 6 & 35 & 597 & $15.3^{\mathrm{a}}$ & 1.29 & 134 & $3.49^{\circ}$ & 0.56 & $21.4^{\mathrm{a}}$ & 2.1 \\
Consecutive & 6 & 53 & 671 & $10.8^{\mathrm{b}}$ & 1.06 & 146 & $2.20^{\circ}$ & 0.46 & $20.7^{\mathrm{a}}$ & 1.9 \\
\hline a:b $\mathrm{P}<0.05$ &
\end{tabular}

Linear regression analysis of the association of repeated follicular aspiration on follicle number for the different follicular populations showed that the number of follicles $£ 10 \mathrm{~mm}$ diameter was not significantly influenced by repeated follicular aspiration. Unlike this, the number of follicles from 10 to $20 \mathrm{~mm}$ diameter decreased significantly, by an average of 1.5 follicles, from one session to the next. The numbers of follicles 21 to $30 \mathrm{~mm}$, and > $30 \mathrm{~mm}$ diameter, were also significantly influenced by repeated follicular aspiration and decreased by an average of 0.8 and 0.1 follicles from one session to the next, respectively.

After the cyclic follicular aspiration session $28.8 \%$ of all COCs (SE $7.6 \%$ ) had compact cumulus investment. The same portion was increased significantly by repeated follicular aspiration to $51.9 \%$ (SE $5.9 \%$ ). At the same time the portions of COCs with few cumulus cell layers, with expanded cumulus or without cumulus cells were reduced (Tab. 5). Mostly reduced was the portion of COCs with few cumulus cell layers.

Tab 5 Morphology of COCs in dependence on type of aspiration session Morphologie von COK in Abhängigkeit vom Typ der Aspirationssitzung

\begin{tabular}{lccccc}
\hline COC morphology & \multicolumn{5}{c}{ Portion of recovered COCs } \\
& Cyclic session & Consecutive sessions & \\
& LSM & SE & LSM & SE & \\
& $(\%)$ & $(\%)$ & $(\%)$ & $(\%)$ & \\
Compact COCs & 28.8 & 7.6 & 51.9 & 5.9 & 0.02 \\
Expanded COCs & 29.5 & 6.3 & 23.8 & 4.9 & 0.47 \\
COCs with few cumulus cell layers & 31.2 & 6.5 & 19.6 & 5.0 & 0.16 \\
Denuded oocytes & 10.5 & 4.7 & 8.8 & 3.7 & 0.79 \\
\hline
\end{tabular}

The portion of COCs with compact cumulus cell layers was also influenced by the time between consecutive aspiration sessions. Shorter time intervals ( 4 to 8 days) between sessions led to a significantly higher portion of compact COCs $(52.6$ $\%$ vs. $23.8 \%$ ) than longer intervals (9 to 12 days). A linear regression analysis of time interval $(\mathrm{x})$ versus portion of compact COCs (y) shows that the portion of COCs with compact cumulus decreased by $4.1 \%$ from one session to the next. Also the meiotic configuration of the recovered COCs with compact cumulus investment was influenced by the type of aspiration session. After the cyclic aspiration sessions in 36.8 $\%$ of the compact COCs a clear germinal vesicle was observed with diplotene configuration. Forty two percent of the oocytes with compact cumulus cells showed different chromatin categories like GVBD and M l, and $7.9 \%$ were in metaphase II. After consecutive sessions the portion of oocytes in the geminal vesicle stage increased significantly whereas the portion of oocytes in GVBD and M I significantly decreased (Tab. 6). There was no significant difference between cyclic and consecutive aspirations in the proportion of degenerating oocytes (13.2 vs. $21.9 \%)$.

Tab 6 Chromatin categories in horse oocytes in dependence on type of aspiration session

Chromatinkonfiguration in Stutenoozyten in Abhängigkeit vom Typ der Aspirationssitzung

\begin{tabular}{|c|c|c|c|c|}
\hline \multirow[b]{2}{*}{ Aspiration } & \multicolumn{4}{|c|}{ Chromatin configuration } \\
\hline & Diffuse GV & GVBD to $\mathrm{Ml}$ & MII & Degenerated \\
\hline & $36.8 \%^{a}$ & $42.1 \%^{a}$ & $7.9 \%^{a}$ & $13.2 \%^{a}$ \\
\hline Cyclic aspiration & $(n=14)$ & $(n=16)$ & $(n=3)$ & $(n=5)$ \\
\hline Consecutive & $65.9 \%^{b}$ & $4.9 \%^{b}$ & $7.3 \%^{a}$ & $21.9 \%^{a}$ \\
\hline aspiration & $(n=27)$ & $(n=2)$ & $(\mathrm{n}=3)$ & $(n=9)$ \\
\hline
\end{tabular}

$a: b \quad P<0.05$ 


\section{Conclusions}

Ultrasound guided follicular aspiration can be done repeatedly in mares without interfering with their later cyclicity or fertility.

Results of ultrasound-guided oocyte recovery are influenced not only by the number of follicles aspirated per mare and aspiration session, but also by the portion of follicles in different classes according to their diameter. The portion of follicles in different classes depends on stage of oestrous cycle and ovarian activity.

Significant differences between mares regarding the number of aspirated follicles per aspiration session permit to distinguish between "good" and "bad" donors. Repeated follicular aspiration can be used to induce a more uniform follicular population and can provide the user with more uniform COCs. The optimum time between aspirations that provides the greatest number of meiotically competent oocytes still must be determined.

\section{Literature}

Brück I., B. Synnestvedt und T. Greve (1997): Repeated transvaginal oocyte aspiration in unstimulated and FSH-treated mares. Theriogenology 47, 1157-1167
Duchamp G., J. Bézard and E. Palmer (1995): Oocyte yield and the consequences of puncture of all follicles larger than 8 millimetres in mares. Biology of Reproduction Mono 1, 233-241

Goudet G., J. Bézard, G. Duchamp, N. Gérard und E. Palmer (1997): Equine oocyte competence for nuclear and cytoplasmic in vitro maturation: effect of follicle size and hormonal environment. Biology of Reproduction 57, 232-245

Kanitz W., F. Becker, H. Alm und H. Torner (1995): Ultrasound-guided follicular aspiration in mares. Biology of Reproduction Mono 1, 225-231

Meintjes M., M. S. Bellow, J. B. Paul, J. R. Broussard, L. Y. Li, D. Paccamonti, B. E. Eilts und R. A. Godke (1995): Transvaginal ultrasound-guided oocyte retrieval from cyclic and pregnant horse and pony mares for in vitro fertilization. Biology of Reproduction Mono $1,281-292$

Torner H. und H. Alm (1995): Meiotic configuration of horse oocytes in relation to the morphology of the cumulus-oocyte complex. Biology of Reproduction Mono 1, 253-259

Supported by Deutsche Forschungsgemeinschaft (Ka 1045/1-3)

PD Dr. habil. Wilhelm Kanitz

Research Institute for the Biology of Farm Animals

Department of Reproductive Biology

Wilhelm-Stahl-Allee 2, D-18196 Dummerstorf

wkanitz@fbn-dummerstorf.de 